\title{
Consolidated Budget Request
}

National Cancer Institute

\section{Source}

National Cancer Institute. Consolidated Budget Request. NCI Thesaurus. Code C39370.

The Consolidated Budget Request is a part of the Cancer Center Support Grant

Application Form PHS 398. It reflects requested budget for the first 12-month period and the summary budget for the entire proposed budget period. 